\title{
PERANAN BAURAN PROMOSI TERHADAP PENINGKATAN VOLUME PEMBIAYAAN PADA PT BPRS RAHMANIA DANA SEJAHTERA BIREUEN DI KABUPATEN BIREUEN
}

\author{
Nurjannah \\ Fakultas Ekonomi dan Bisnis Universitas Islam Kebangsaan Indonesia Bireuen-Aceh
}

\begin{abstract}
ABSTRAK
Penelitian ini bertujuan untuk mengetahui pengaruh penerapan strategi pemasaran yang meliputi Periklanan (Advertising) Periklanan adalah semua bentuk penyajian nonpersonal, promosi ideide, promosi barang atau jasa yang dilakukan oleh sponsor yang dibayar, Promosi Penjualan (Sales Promotion) Promosi penjualan adalah variasi insentif jangka pendek untuk merangsang pembelian atau penjualan suatup roduk atau jasa, Hubungan Masyarakat dan Publisitas (Public Relation and Publicity), Hubungan Masyarakat adalah suatu usaha (variasi) dari rancangan program guna memperbaiki, mempertahankan, atau melindungi perusahaan atau citra produk, Penjualan Persoanal (Personal Selling), Penjualan pribadi atau tatap muka adalah penyajian lisan dalam suatu pembicaraan dengan satu atau beberapa pembeli potensial dengan tujuan untuk melakukan penjualan. Pemasaran Langsung (Direct Marketing) komunikasi secara langsung yang digunakan dari mail, telepon, fax, e-mail, atau internet untuk mendapatkan tanggapan langsung dari konsumen secara jelas.Sampel pada penelitian ini adalah data yang di peroleh pihak manajemen dan nasabah yang menggunakan produk pembiayaan di PT BPRS Rahmania Dana Sejahtera, dalam bentuk wawancara dan analisa data yang dimiliki oleh perusahaan.
\end{abstract}

Kata kunci: Bauran Promosi, Peningkatan Volume Pembiayaan

\section{ABSTRACT}

This study aims to determine the effect of the implementation of a marketing strategy that includes advertising (Advertising) Advertising is all forms of presentation nonpersonal, promotional ideas, promotion of goods or services performed by the sponsor who paid, Sales Promotion (Sales Promotion) Sales promotion is a variation term incentives short to stimulate the purchase or sale of a product or service, public Relations and Publicity (public Relations and Publicity) public relations is an attempt (variation) of the draft program to improve, maintain, or protect the company or product image sales Persoanal (Personal selling) sales personal or face-to-face is the oral presentations in a conversation with one or several potential buyers for the purpose of sale of direct Marketing (direct Marketing) Communication direct use of mail, telephone, fax, e-mail or the internet to get direct feedback from consumers clearly. Samples of these data is obtained from management and customers who use financial products in PT BPRS Rahmania Dana Sejahtera, both in interviews and analsis data.

Keywords: Campaign Against Mix, Volume Increase Funding

\section{PENDAHULUAN}

Bank syariah pertama kali di Indonesia adalah Bank Muamalat Indonesia yang didirikan pada tahun 1991 dan resmi beroperasi sejak tahun 1992. Selanjutnya disusul oleh Bank Syariah lain yang berdiri 
dalam bentuk Unit Usaha Syariah (UUS), Bank Umum Syariah (BUS), maupun Bank Pembiayaan Rakyat Syariah (BPRS).

Bank Pembiayaan Rakyat Syariah (BPRS) sebelumnya disebut sebagai Bank Pengkreditan Rakyat Syariah (BPRS) yang melakukan kegiatan usaha berdasarkan prinsip syariah yang didalamnya tidak memberikan jasa dalam lalu lintas pembayaran.

Kegiatan usaha Bank Pembiayaan Rakyat Syariah (BPRS) meliputi : (a) Menghimpun dana dari masyarakat dalam bentuk: (1) Simpanan berupa tabungan atau yang dipersamakan dengan itu berdasarkan akad wadiah atau akad lain yang tidak bertentangan dengan prinsip syariah, (2) Investasi berupa deposito atau tabungan atau bentuk lain yang dipersamakan dengan itu berdasarkan akad mudharabah atau akad lain yang tidak bertentangan dengan Syariah; (b) Menyalurkan dana kepada masyarakat dalam bentuk: (1) Pembiayaan bagi hasil berdasarkan akad mudharabah atau musyaraka, (2) Pembiayaan berdasarkan akad murabahah, salam atau isti'na, (3) Pembiayaan berdasarkan akad qardh, (4) Pembiayaan penyewaan barang bergerak atau tidak bergerak kepada nasabah berdasarkan akad ijarah, dan sewa beli dalam bentuk akad ijarah muntahiyah bittamlik, (5) Pengambil alihan utang berdasarkan akad wakalah; (6) Menempatkan dana pada Bank Syariah lain dalam bentuk titipan berdasarkan akad wadiah atau investasi berdasarkan akad mudharabah dan/atau akad lain yang tidak bertentangan dengan prinsip Syariah; (7) Memindahkan uang, baik untuk kepentingan sendiri maupun untuk kepentingan nasabah melalui rekening Bank Pembiayaan Rakyat Syariah (BPRS) yang ada di Bank Umum Syariah, Bank Umum Konvensional, dan Unit Usaha Syariah (UUS); Menyediakan produk atau melakukan kegiatan usaha Bank Syariah lainnya yang sesuai dengan prinsip Syariah berdasarkan persetujuan Bank Indonesia atau Otoritas Jasa Keuangan (OJK) Republik Indonesia.

Bank Pembiayaan Rakyat Syariah (BPRS) dilarang : (a) Melakukan kegiatan usaha yang bertentangan dengan prinsip syariah; (b) Menerima simpanan berupa giro dan ikut serta dalam lalu lintas pembayaran; (c) Melakukan kegiatan usaha dalam valuta asing, kecuali menukar uang asing dengan izin Bank Indonesia atau Otoritas Jasa Keuangan (OJK); (d) Melakukan usaha lain di luar kegiatan usaha BPRS. Dari penjelasan diatas tentang kegiatan usaha, Bank Pembiayaan Rakyat Syariah (BPRS) memerlukan dana untuk mejalankan operasional perusahaan seperti penyaluran pembiayaan kepada masyarakat. Dana tersebut dapat diperoleh dari pemegang saham, pemerintah, Bank Indonesia, masyarakat diluar daerah maupun di dalam daerah.

Dana dari pemegang saham (pemilik bank) merupakan penanaman modal yang disetor pada saat pendirian bank dan setelahnya. Dana dari pemerintah diperoleh apabila bank yang bersangkutan ditunjuk untuk menyalurkan dana masyarakat sedangkan dana masyarakat baik di luar daerah maupun dalam daerah dihimpun oleh bank dengan menggunakan produk simpanan yang terdiri dari deposito dan tabungan. Bagian terpenting dari instrumen pemasaran produk perbankan adalah pesan yang dikomunikasikan kepada calon nasabah melalui berbagai unsur yang terdapat dalam program promosi. Program promosi merupakan saluran primer bagi komunikasi pesan kepada nasabah, baik nasabah ada maupun nasabah yang potensial. Hal ini mengharuskan pihak perbankan untuk mencermati strategistrategi pemasaran yang paling tepat.

Dengan dasar inilah, maka setiap lembaga keuangan selalu melakukan evaluasi dalam menerapkan strategi dan cara pelaksanaan kegiatan pemasarannya, sebab 
sebagaimana diketahui bahwa keadaan didunia perbankan bersifat dinamis yang selalu mengalami perubahan dari waktu ke waktu. Oleh karena itu setiap lembaga keuangan selalu menerapkan strategi dan cara melaksanakan kegiatan pemasarannya. Kegiatan pemasaran yang dilakukan, diarahkan untuk dapat mencapai sasaran yang telah direncanakan oleh lembaga keuangan dan meningkatkan jumlah laba. Faktor internal dan eksternal merupakan pendorong yang mengharuskan setiap bank untuk bisa mengantisipasi dan beradaptasi dengan perubahan yang terjadi, tidak dijadikan sebagai ancaman, tetapi dapat menjadi peluang untuk mengembangkan usaha dan memperoleh keuntungan yang besar.

PT Bank Pembiayaan Rakyat Syariah (BPRS) Rahmania Dana Sejahtera dalam melaksanakan kegiatan usahanya menghadapi persaingan dengan lembaga keuangan/bank-bank lain dalam memasarkan produk jasanya kepada masyarakat. Untuk menghadapi hal tersebut dan meningkatkan volume pembiayaan, PT BPRS Rahmania Dana Sejahtera telah menerapkan bauran promosi untuk merebut pasar sasarannya sehingga volume pembiayaan yang ditargetkan tercapai. Keberhasilan dalam merebut pasar sasarannya dan mengantisipasi setiap perubahan yang terjadi dalam lingkungan pemasaran PT Bank Pembiayaan Rakyat Syariah Rahmania Dana Sejahtera mengalami perkembangan yang cukup pesat dalam meningkatkan usahanya, hal ini disebabkan kebijakan Promosi yang diterapkan cukup mampu menarik minat masyarakat untuk menggunakan jasa pembiayaan di PT Bank Pembiayaan Rakyar Syariah Rahmania Dana Sejahtera.

Penelitian ini akan fokus pada menganalisis Bauran Promosi Terhadap Peningkatan Volume Pembiayaan Pada PT BPRS Rahmania Dana Sejahtera Kabupaten Bireuen

\section{Landasan Teoritis}

\section{Pengertian Bauran promosi}

Salah satuunsur dalam strategi pemasaran adalah bauran promosi (Promotion mix) yang merupakan alat pemasar yang terdiri atas berbagai unsur program pemasaran yang perlu dipertimbangkan agar implementasi promosi dan positioning yang ditetapkan dapat berjalan sukses. Bauran promosi pada produk barang yang kita kenal selama ini berbeda dengan bauran promosi untuk produk jasa. Hal ini berkaitan dengan perbedaan katakteristik barang dan jasa.

Bauran promosi dapat diartikan sebagai suatu kombinasi dari variabel pemasaran yang digunakan untuk mencapai tujuan pemasaran. Beberapa pengertian dari pada bauran promosi atau promotion mix adalah :

Pengertian promosi menurut Djaslim Saladin dan Yevis Marty Oesman (2002:123) "Promosi adalah suatu komunikasi informasi penjual dan pembeli yang bertujuan untuk merubah sikap dan tingkah laku pembeli, yang sebelumnya tidak mengenal menjadi mengenal sehingga menjadi pembeli dan mengingat produk tersebut".

Sedangkan pengertian promosi menurut Buchari Alma (2006 : 179) adalah: "Promosi adalah sejenis komunikasi yang memberi penjelasan dan meyakinkan calon konsumen mengenai barang dan jasa dengan tujuan untuk memperoleh perhatian, mendidik, mengingatkan dan meyakinkan calon konsumen".

Adapun bauran promosi menurut Plilip Kotler yang tercantum dalam buku karangan Drs. Djaslim Saladin (2004 : 172) adalah sebagai berikut :

1. Periklanan (Advertising) Periklanan adalah semua bentuk penyajian nonpersonal, promosi ide-ide, promosi barang atau jasa yang dilakukan oleh sponsor yang dibayar.

2. Promosi Penjualan (Sales Promotion) Promosi penjualan adalah variasi 
insentif jangka pendek untuk merangsang pembelian atau penjualan suatu produk atau jasa.

3. Hubungan masyarakat dan Publisitas (Public Relation and Publicity) Hubungan masyarakat adalah suatu usaha (variasi) dari rancangan program guna memperbaiki, mempertahankan, atau melindungi perusahaan atau citra produk.

4. Penjualan Persoanal (Personal Selling) Penjualan pribadi atau tatap muka adalah penyajian lisan dalam suatu pembicaraan dengan satu atau beberapa pembeli potensial dengan tujuan untuk melakukan penjualan.

5. Pemasaran Langsung (Direct Marketing) Komnikasi secara langsung yang digunakan dari mail, telepon, fax, e-mail, atau internet untuk mendapatkan tanggapan langsung dari konsumen secara jelas.

Menurut Kotler (2010 : 174) bauran promosi (promotion mix) terdiri atas delapan unsur atau metode bauran promosi, diuraikan sebagai berikut:

1. Periklanan (Advertising )

Semua bentuk terbayar dari presentasi nonpersonal, dan promosi ide, barang atau jasa melalui sponsor yang jelas.

2. Promosi Penjualan ( Sales Promotion ) Berbagai insentif jangka pendek untuk mendorong pembelian atau penjualan suatu produk atau jasa seperti pameran dagang, insentif penjualan, kupon, dan sebagainya.

3. Acara dan Pengalaman ( Event \&

\section{Experiece )}

Kegiatan dan program yang disponsori perusahaan yang dirancang untuk menciptakan interaksi harian atau interaksi yang berhubungan dengan merek tertentu.

4. Hubungan Masyarakat atau Publisitas (

\section{Public Relation )}

Beragam program yang dirancang untuk mempromosikan atau melindungi citra perusahaan atau produk individunya.
5. Pemasaran Langsung ( Direct

Marketing )

Penggunaan surat, telepon, faximile, email, atau internet untuk berkomunikasi secara langsung dengan atau meminta respon atau dialog dari pelanggan dan prospek tertentu.

6. Pemasaran Interaktif (Interactive Marketing )

Kegiatan dan program online yang dirancang untuk melibatkan pelanggan atau prospek dan secara langsung atau tidak langsung meningkatkan kesadaran, memperbaiki citra, atau menciptakan penjualan produk dan jasa.

7. Pemasaran dari Mulut ke Mulut (Mouth of Mouth )

Komunikasi lisan, tertulis, dan elektronik antar masyarakat yang berhubungan dengan keunggulan atau pengalaman membeli atau menggunakan produk atau jasa.

8. Penjualan Personal ( Personal Selling) Interaksi tatap muka dengan satu atau lebih pembeli prospektif untuk tujuan melakukan presentasi, menjawab pertanyaan dan pengadaan pesanan.

\section{Pengertian pembiayaan}

Adapun pengertian pembiayaan menurut berbagai litertur yang ada sebagai berikut :

Undang-Undang No 10 tahun 1998 : "Pembiayaan adalah penyediaan uang atau tagihan yang dapat dipersamakan dengan itu, berdasarkan persetujuan atau kesepakatan antara bank dengan pihak lain yang mewajibkan pihak yang dibiayai untuk mengembalikan uang atau tagihan tersebut setelah jangka waktu tertentu dengan imbalan atau bagi hasil."

Menurut Muhammad Syafii Antonio. $(2001 ; 16)$, Bank syariah dari teori ke Praktek: "Pembiayaan adalah pemberian fasilitas penyediaan dana untuk memenuhi kebutuhan pihak-pihak yang merupakan defisit unit" 
Menurut Muhammad (2002;260), Manajemen Dana Bank Syariah. "Pembiayaan dalam secara luas diartikan sebagai pendanaan yang dikeluarkan untuk mendukung investasi yang telah direncanakan baik dilakukan sendiri maupun dijalankan oleh orang lain"

Berdasarkan pengertian tersebut diatas, dapat disimpulkan bahwa pembiayaan adalah pemberian fasilitas penyediaan dana untuk mendukung investasi yang telah direncanakan berdasarkan kesepakatan antara bank dengan pihak lain yang mewajibkan pihak yang dibiayai untuk mengembalikan uang atau tagihan tersebut setelah jangka waktu tertentu dengan imbalan atau bagi hasil.

Menurut Muhammad (2002:91) Manajemen Dana Bank Syariah."Penyaluran dananya pada nasabah, secara garis besar produk pembiayaan syariah terbagi dalam empat katagori yang dibedakan berdasarkan tujuan penggunaanya yaitu :

1. Pembiayaan dengan prinsip jual beli (ba'i) : prinsip jual beli ini dilaksanakan sehubungan dengan adanya perpindahan kepemilikan barang atau benda (transfer of property) tingkat keuntungan ditentukan didepan dan menjadi bagian harga atas barang yang dijual. Transaksi jual beli dapat dibedakan berdasarkan bentuk pembayaran dan waktu penyerahan yakni sebagai berikut:
a. Pembiayaan murabahah
b. Pembiayaan salam
c. Pembiayaan isti'na.

2. Pembiayaan dengan prinsip sewa (Ijarah) : transaksi ijarah dilandasi oleh adanya perpindahan manfaat. Jadi pada dasarnya prinsip ijarah sama saja dengan prinsip jual beli, tapi perbedaannya terletak pada objek transaksinya. Bila pada jual beli objek transaksinya adalah barang, pada ijarah objek transaksinya adalah jasa. Pada akhir sewa, bank dapat saja menjual barang yang disewakan kepada nasabah.

3. Produk pembiayaan syariah yang didasarkan atas prinsip bagi hasil adalah sebagai berikut :

a. Pembiayaan musyarakah

b. Pembiayaan mudharabah

4. Pembiayaan dengan akad pelengkap, untuk mempermudah pelaksanaan pembiayaan, biasanya diperlukan akad pelengkap. Akad pelengkap ini tidak ditujukan untuk mencari keuntungan, tetapi di tujukan untuk mempermudah pelaksanaan pembiayaan, dalam akad pelengkap ini dibolehkan untuk meminta biaya-biaya yang dikeluarkan untuk melaksanakan akad ini. Adapun jenis-jenis akad pelengkap ini adalah sebagai berikut :

a. Hilwalah (alih hutang - piutang)

b. Rahn (gadai)

c. Qardh

d. Wakalah (perwakilan)

e. Kafalah (garansi bank)

Sedangkan menurut sifat penggunaanya, pembiayaan dapat dibagi menjadi dua hal, yaitu :

1. Pembiayaan produktif, yaitu pembiayaan yang ditujukan untuk memenuhi kebutuhan produksi dalam arti luas, yaitu untuk meningkatkan usaha baik usaha produksi, perdagangan, maupun investasi.

2. Pembiayaan konsumtif, yaitu pembiayaan yang dipergunakan untuk memenuhi kosumsi, yang akan habis digunakan untuk memenuhi kebutuhan.

\section{Pengertian Bank Syariah}

Pada Undang-Undang No 10 tahun 1998 tentang perubahan UU No 7 tahun 1992 tentang perbankan pasal (1) disebutkan bahwa :

"Prinsip syariah adalah aturan perjanjian berdasarkan hukum Islam antara bank dan pihak lain untuk menyimpan dana dan atau pembiayaan kegiatan usaha, atau kegiatan lainnya yang dinyatakan sesuai dengan syariah, antara lain : pembiayaan berdasarkan prinsip bagi hasil (mudharabah), pembiayaan berdasarkan 
prinsip penyertaan modal (musyarakah), prinsip jual beli barang dengan memperoleh keuntungan (murabahah), atau pembiayaan barang modal berdasarkan prinsip sewa murni tanpa pilihan (ijarah) atau dengan adanya pilihan pemindahan kepemilikian atas barang yang disewakan dari pihak bank oleh pihak lain (ijarah wa isti'na)".

Pada Undang-Undang Nomor 21 tahun 2008 tentang perbankan syariah mendefinisikan bank syariah sebagai bank yang menjalankan kegiatan usahanya berdasarkan prinsip syariah dan menurut jenisnya terdiri atas Bank Umum Syairah (BUS) dan Bank Pembiayaan Rakyat Syariah (BPRS).

Dari pengertian diatas dapat di simpulkan bahwa Bank Pembiayaan Syariah (BPRS) yang sebelumnya disebut sebagai Bank Pengkreditan Rakyat Syariah (BPRS) adalah bank yang melakukan kegiatan usaha berdasarkan prinsip syariah yang dalam kegiatanya tidak memberikan jasa dalam lalu lintas pembayaran.

Menurut Muhammad Syafi'i Antonio (2001;40) Bank syariah mempunyai fungsi secara umum meliputi sebagai berikut :
a. Bertanggung jawab terhadap penyimpanan dana nasabah
b. Mengelola investasi dari dana yang diperoleh
c. Penyedia transaksi keuangan
d. Pengelola zakat, infaq dan shadakah

Kegiatan dan fungsi dari usaha Bank

Pembiayaan Rakyat Syariah (BPRS) meliputi :

1. Menghimpun dana dari masyarakat dalam bentuk:

a. Simpanan berupa tabungan atau yang dipersamakan dengan itu berdasarkan akad wadiah atau akad lain yang tidak bertentangan dengan prinsip syariah;

b. Investasi berupa deposito atau tabungan atau bentuk lain yang dipersamakan dengan itu berdasarkan akad mudharabah atau akad lain yang tidak bertentangan dengan prinsip syariah;

2. Menyalurkan dana kepada masyarakat dalam bentuk:

a. Pembiayaan bagi hasil berdasarkan akad mudharabah atau musyarakah;

b. Pembiayaan berdasarkan akad murabahah, salam atau isti'na;

c. Pembiayaan berdasarkan akad qardh;

d. Pembiayaan penyewaan barang bergerak atau tidak bergerak kepada nasabah berdasarkan akad ijarah atau sewa beli dalam bentuk ijarah muntahiyah bittamlik;

e. Pengambil alihan utang berdasarkan akad hawalah;

3. Menempatkan dana pada bank syariah lain dalam bentuk titipan berdasarkan akad wadiah atau investasi berdasarkan akad mudharabah dan/atau akad lain yang tidak bertentangan dengan prinsip syariah;

4. Memindahkan uang, baik untuk kepentingan sendiri maupun untuk kepentingan nasabah melalui rekening Bank Pembiayaan Rakyat Syariah (BPRS) yang ada di bank umum syariah, bank umum konvensional, dan Unit Usaha Syariah (UUS);

5. Menyediakan produk atau melakukan kegiatan usaha bank syariah lainnya yang sesuai dengan prinsip syariah berdasarkan persetujuan Bank Indonesia atau Otoritas Jasa Keuangan (OJK) Republik Indonesia.

Menurut Ikatan Akutansi Indonesia "Bank Syariah adalah bank yang berasas kemitraan, keadilan, transparansi dan universal serta melakukan kegiatan usaha perbankan berdasarkan prinsip syariah.”

Kegiatan bank syariah merupakan implementasi dari prinsip ekonomi Islam dengan karakteristik, antara lain sebagai berikut :

1. Pelarangan riba dalam berbagai bentuknya

2. Tidak mengenal konsep nilai waktu dari uang (time value of money) 
Jurnal Sosial Humaniora Sigli (JSH)

p ISSN : 2615-3688

$e$ ISSN : 2716-0270

http://journal.unigha.ac.id/index.php/JSH

3. Konsep uang sebagai alat tukar bukan sebagai komuniti

4. Tidak diperkenankan menggunakan dua harga untuk satu barang

5. Tidak diperkenankan dua transaksi dalam satu akad

Bank syariah beroperasi atas dasar konsep bagi hasil. Bank syariah tidak menggunakan bunga sebagai alat untuk memperoleh pendapatan maupun membebankan bunga atas penggunaan dana dan pinjaman karena bunga merupakan riba yang diharamkan.

Berbeda dengan bank non syariah, bank syariah tidak membedakan secara tegas antara sektor moneter dan sektor riil sehingga dalam kegiatan usahanya dapat melakukan transaksi-transaksi sektor riil, seperti jual beli dan sewa menyewa. Di samping itu, bank syariah juga dapat menjalankan kegiatan usaha untuk memperoleh imbalan atas jasa perbankan lain yang tidak bertentangan dengan prinsip syariah.

Menurut Ikatan Akutansi Indonesia "Suatu transaksi sesuai dengan prinsip syariah apabila telah memenuhi seluruh syarat berikut ini :

1. Transaksi tidak mengandung unsur kedzaliman

2. Bukan riba

3. Tidak membahayakan pihak sendiri atau pihak lain

4. Tidak ada penipuan (gharar)

5. Tidak mengandung materi-materi yang diharamkan

6. Tidak mengandung unsur judi (maisyir)"

Jadi dalam oprasional bank syariah perlu memerhatikan hal yang telah diatur oleh syariah atau ajaran Islam yang berkaitan dengan harta, uang, jual beli, dan transaksi ekonomi lainnya. Bank syariah dalam menjalankan usahanya tidak dapat dipisahkan dari konsep syariah yang mengatur produk dan operasionalnya. Konsep dasar syariah akan dijadikan pijakan dalam mengembangkan produk bank syariah.

\section{Kerangka Pemikiran}

Berdasarkan tinjauan pustaka yang telah dikemukakan, penelitian ini bertujuan untuk menganalisa bauran promosi yang digunakan oleh PT Bank Pembiayaan Rakyat Syariah Rahmania Dana Sejahtera Kabupaten Bireuen yang terdiri dari Periklanan (Advertising), Promosi Penjualan (Sales Promotion), Acara dan Pengalaman (Event \& Experiece), Hubungan Masyarakat atau Publisitas (Public Relation), Pemasaran Langsung (Direct Marketing), Pemasaran Interaktif (Interactive Marketing), Pemasaran dari Mulut ke Mulut (Mouth of Mouth), Penjualan Personal (Personal Selling).Maka penulis menjabarkan kerangka pemikiran teoritis yang akan dijadikan acuan dan pegangan dalam penelitian ini dalam gambar sebagai berikut

\section{Gambar 2.1. Kerangka Pemikiran}

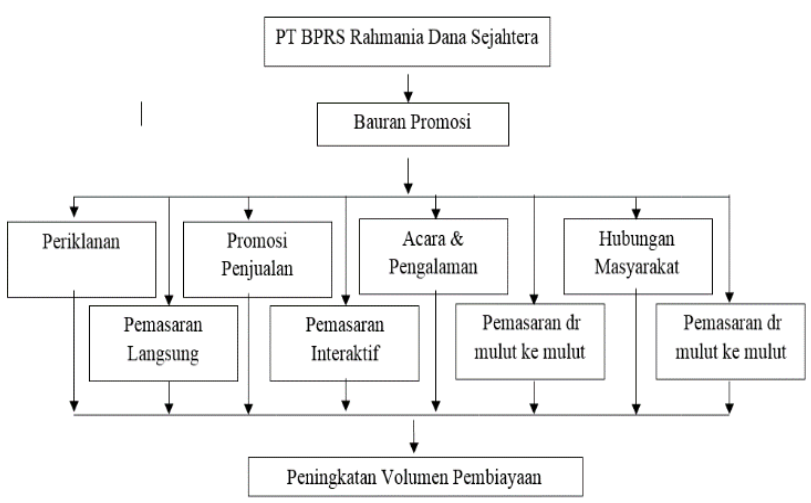

\section{METODE PENELITIAN}

Penelitian kualitatif yang bersifat deskriptif analitik. Data yang diperoleh seperti hasil pengamatan, hasil wawancara, hasil pemotretan, analisis dokumen, catatan lapangan, disusun peneliti di lokasi penelitian, tidak dituangkan dalam bentuk dan angka-angka. Peneliti melakukan analisis data dengan memperkaya informasi, mencari hubungan, membandingkan, menemukan pola atas dasar data aslinya (tidak ditransformasi dalam bentuk angka). 
Hasil analisis data berupa pemaparan mengenai situasi yang diteliti yang disajikan dalam bentuk uraian naratif. Hakikat pemaparan data pada umumnya menjawab pertanyaan-pertanyaan mengapa dan bagaimana suatu fenomena terjadi. Untuk itu peneliti dituntut memahami dan menguasai bidang ilmu yang diteliti sehingga dapat memberikan justifikasi mengenai konsep dan makna yang terkandung dalam data yang diperoleh.Penelitian ini akan dilakukan di PT Bank Pembiayaan Rakyat Syariah Rahmania Dana Sejahtera Kabupaten Bireuen yang beralamat di Jalan T Panglima Polem No 36 Gampong Bandar Bireuen Kecamatan Kota Juang Kabupaten Bireuen Provinsi Aceh.

\section{Metode Analisis Data}

Pengujian keabsahan mengenai hipotesis, dilakukan penganalisis data yang telah dikumpulkan. Teknis yang digunakan adalah teknis analisis deskriptif dan deduktif.

1. Teknis analisis deskriptif

Suatu metode yang berusaha mengumpulkan, mengklasifikasikan serta memaparkan data sehingga dapat memberikan keterangan lengkap mengenai masalah yang dibahas

2. Teknis analisis deduktif

Suatu analisa yang menggunakan teoriteori yang berlaku umum sebagai dasar kebenaran. Kemudian menarik kesimpulan atas data yang diamati

\section{Hasil Penelitian}

Data dari hasil penelitian yang didapatkan pada PT BPRS Rahmania Dana Sejahtera Kabupaten Bireuen didapatkan melalui observasi, wawancara dan dokumentasi mengacu kepada peningkatan volume pembiayaan pertahun yang berimbas keberbagai aspek di perusahaan dan pelayanan terhadap konsumen oleh pegawai perusahaan.
Data rincian peningkatan volume dalam 5 tahun, dimulai dari tahun 2011 yang pencapaiannya Rp. 1.043.699.000,- (Satu milyar empat puluh tiga juta enam ratus sembilan puluh sembilan ribu rupiah) untuk tahun 2012 pencapaian perusahaan bergerak ke nominal Rp. 2.593.268.000,- (Dua milyar lima ratus sembilan puluh tiga juta dua ratus enam puluh delapan ribu rupiah) dan angka pertumbuhannya adalah $\mathrm{Rp}$. 1.549.569.000,- (Satu milyar lima ratus empat puluh sembilan juta lim ratus enam puluh sembilan ribu rupiah) berarti persentase peningkatan perusahaan adalah $59,75 \%$.

Pada tahun 2013 secara kuantitas mengalami peningkatan sebesar Rp. 3.397.632.000,- (Tiga milyar tiga ratus sembilan puluh tujuh juta enam ratus tiga puluh dua ribu rupiah) dibandingkan tahun sebelumnya dengan selisih pertumbuhan Rp. 804.364.000,- (Delapan ratus empat juta tiga ratus enam puluh empat ribu rupiah) serta persentase pertumbuhannya $23,67 \%$.

Pertumbuhan pada tahun 2014, perusahaan tetap mengalami peningkatan volume pembiayaan sebesar Rp. 3.856.948.000,- (Tiga milyar delapan ratus lima puluh enam juta sembilan ratus empat puluh delapan ribu rupiah) dengan selisih pertumbuhan Rp. 459.316.000,- (Empat ratus lima puluh sembilan juta tiga ratus enam belas ribu rupiah) dan persentase pertumbuhan $11,90 \%$.

Sedangkan pada tahun 2015 yang merupakan hasil terakhir data yang didapat dari penelitian ini adalah realisasi peningkatan volume yang berjumlah $\mathrm{Rp}$. 5.544.069.000,- (Lima milyar lima ratus empat puluh empat juta enam puluh sembilan ribu rupiah) dengan angka pertumbuhan perusahaan Rp.1.687.121.000,- (Satu milyar enam ratus delapan puluh tujuh juta seratus dua puluh satu ribu rupiah) dengan persentase pertumbuhannya adalah $30,43 \%$.

Hasil akhir dari penelitian ini, perusahaan di tempat penulis melakukan 
penelitian mengembangkan bauran promosi untuk meningkatkan volume pembiayaannya selama rentang waktu lima tahun memperoleh peningkatan dengan selisih pencapaian dari tahun 2011 sebesar Rp. 1.043.699.000,- (Satu milyar empat puluh tiga juta enam ratus sembilan puluh sembilan ribu rupiah) dan tahun 2015 adalah Rp. 5.544.069.000,- (Lima milyar lima ratus empat puluh empat juta enam puluh sembilan ribu rupiah) sehingga diperoleh peningkatan sebesar Rp. 4.500.370.000,(Empat milyar lima ratus juta tiga ratus tujuh puuh ribu rupiah) dengan persentase pertumbuhan perusahaan mencapai $81,17 \%$.

Pencapaian dan peningkatan volume pembiayaan yang diteliti dalam rentang waktu lima tahun dapat dilihat melalui grafik 4.1 dan grafik 4.2.

Grafik. 4.1

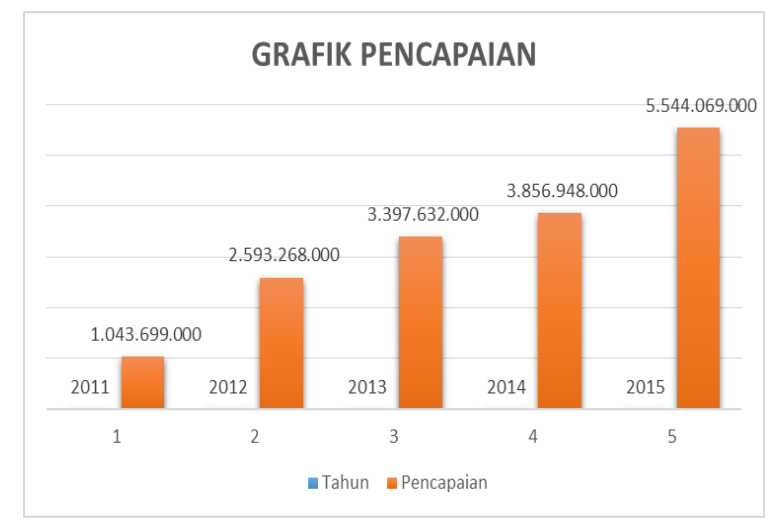

Grafik 4.2

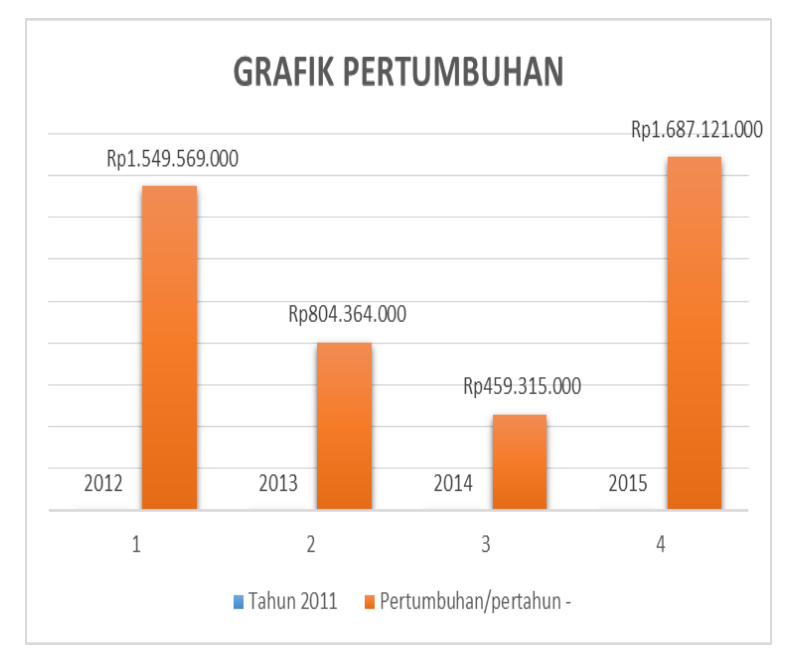

\section{PEMBAHASAN}

PT BPRS Rahmania Dana Sejahtera Kabupaten Bireuen dalam rentang waktu lima tahun menurut penulis kegiatan bauran promosi yang dilakukan oleh perusahaan selama ini sangat berpengaruh terhadap peningkatan volume pembiayaan yang diberikan kepada nasabah. Dalam penelitian yang dilakukan, kegiatan bauran promosi yang dijalankan oleh perusahaan belum terencana dan terstruktur dengan baik, sehingga perusahaan masih belum dapat memaksimalkan berbagai sumber daya perusahaan untuk penerapan bauran promosi secara maksimal, dikarenakan berbagai kendala internal dan eksternal pada perusahaan. Akan tetapi peningkatan volumen pembiayaan perusahaan terus terjadi setiap tahunnya, ini disebabkan oleh adanya bauran promosi yang terus dilaksanakan oleh perusahaan.

Penulis akan menganalisa keseluruhan bauran promosi yang dilakukan oleh perusahaan selama ini :

\section{Periklanan (Advertising)}

Media periklanan yang dilakukan oleh

PT BPRS Rahmania Dana Sejahtera Kabupaten Bireuen selama ini masih sangat kurang, hal ini dapat dilihat dari tidak adanya iklan di radio dan surat kabar, sehingga nasabah masih kurang mengetahui tentang perusahaan dan produk yang ditawarkan. Untuk memperkenalkan produk kepada calon nasabah atau masyarakat dengan menggunakan spanduk, brosur, percetakan kalender, perusahaan masih sangat sedikit dan terbatas. Hal ini tentunya menjadi kendala bagi perusahaan dalam meningkatkan volumen pembiayaan.

\section{Promosi Penjualan (Sales Promotion)}

Untuk promosi penjualan yang dijalankan perusahaan selama ini masih perlu dikaji lebih lanjut karena calon nasabah masih memilih menggunakan produk yang sama di perusahaan lain dikarenakan promosi penjualan yang 
Jurnal Sosial Humaniora Sigli (JSH)

p ISSN : 2615-3688

$e$ ISSN : 2716-0270

http://journal.unigha.ac.id/index.php/JSH

diterapkan masih kalah bersaing. Bila perusahaan ingin besaing dengan perusahaan lain dalam masalah harga maka perusahaan harus melakukan evaluasi terhadap modal, dan sumber dana yang dimiliki, sehingga produk yang ditawarkan lebih murah dan mendapat potonganpotongan harga yang menarik dari pada perusahaan pesaing yang ada di Kabupaten Bireuen.

\section{Acara dan Pengalaman (Event \& Experiece)}

Perusahaan belum mampu melakukan atau menseponsori kegiatan-kegiatan kemasayarakatan yang bersifat promosi terhadap perusahaan. Ini dikarenakan pengalaman perusahaan yang masih kurang dalam melakukan hal tersebut, juga tidak didukung oleh fasilitas yang dimiliki perusahaan dan terbatasnya dana untuk melakukan dan mensponsori kegiatankegiatan tersebut. Walaupun pengaruh acara yang dilakukan atau disponsori tersebut terhadap pengetahuan masyarakat atau calon nasabah terhadap perusahaan dan produk yang ditawakan sangat besar.

\section{Hubungan Masyarakat atau publisitas (Public Relation)}

Perusahaan jarang mengadakan kegiatan yang bersifat publisitas. Padahal publisitas atau hubungan masyarakat sangat mempengaruhi citra perusahaan di mata masyarakat atau calon nasabah. Ini terlihat dari penghargaan yang diperoleh perusahaan selama lima tahun masih minim. Untuk kedepan perusahaan perlu melakukan kegiatan-kegiatan yang berhubungan langsung masyarakat, karena bauran ini sangat efektif dalam membentuk imag di mata masyarakat bahwa perusahaan dengan dengan mereka dan bisa memberi solusi terhadap persoalan ekonomi yang terjadi.

\section{Pemasaran Langsung (Direct Marketing)}

Pemasaran langsung adalah bentuk promosi yang sangat mudah dan gampang dilakukan, apalagi fasilitas yang dimiliki sudah memadai seperti sudah adanya fasilitas telepon, Hendpon, Fax dan lainlain. Akan tetapi perusahaan belum meksimal dalam menggunakan fasilitas pemasaran langsung, ini disebabkan oleh kurangnya pengetahuan bauran promosi di bagian marketing dan manajemen secara umum. Perlu dilakukan pelatihan-pelatihan tentang direct marketing kepada tenaga marketing dan karyawan.

\section{Pemasaran Interaktif (Interactive Marketing) \\ Dalam melakukan pemasaran} interaktif seperti promosi online, dan sarana lainya perusahaan belum mempunyai tenaga ahli dalam bidang itu. Sehingga sampai sekarang perusahaan belum memiliki wabsate, facebook, twiter, blog bentukbentuk dan lain-lain, media yang sekarang lagi disukai oleh masyarakat.

\section{Pemasaran dari Mulut ke Mulut (words of Mouth)}

Pemasaran dari mulut ke mulut merupakan pemasaran yang sangat efektif dan efesien dalam mempromosikan perusahaan dan produk-produk yang dimiliki, dan juga sangat cepat dalam merubah keputusan masyarakat atau calon nasabah untuk menggunakan produk yang ditawarkan. Dalam hal ini perusahaan menjadikan program unggulan dalam memperkenalkan produk untuk meningkatkan volume pembiayaan, sangat perusahaan menaruh perhatian yang penuh dalam melaksanakan strategi ini. Karena perusahaan menyadari bahwa dengan pemasaran dari mulut ke mulut tidak banyak mengelurkan dana dan sesuai dengan pasar sasaran yang dimiliki.

Bauran promosi ini sangat baik untuk dipertahankan dan dikembangkan dengan strategi-strategi yang lebih menarik karena sangat besar pengaruhnya terhadap peningkatan volume pembiayaan yang diberikan. Apalagi pasar sasaran yang 
Jurnal Sosial Humaniora Sigli (JSH)

p ISSN : 2615-3688

$e$ ISSN : 2716-0270

http://journal.unigha.ac.id/index.php/JSH

dimiliki oleh perusahaan adalah menegah ke bawah dimana mereka lebih banyak mendapat informasi dari mulut ke mulut dari pada bauran promosi lain.

\section{Penjualan Personal (Personal Selling)}

Strategi melalui penjualan personal (personal selling) memberikan sumbangan besar terhadap peningkatan volume pembiayaan perusahaan. Karena ketentuan yang diberikan oleh perusahaan terhadap personal karyawan yang bekerja di bagian marketing adalah menetapkan target yang harus dicapai oleh masing-masing karyawan. Ini menjadi motivasi bagi karyawan dalam melaksanakan tugasnya dan juga karyawan termotivasi untuk saling bersaing dengan sesamanya secara sehat.

Strategi personal selling dengan cara tatap muka dan melakukan dialog langsung dengan masyarakat atau calon nasabah menjadi kegiatan rutinitas yang dilakukan oleh perusahaan untuk meningkatkan volume pembiayaan. Didukung oleh sumber daya insani yang memadai dan menguasai lokasi pasar sasaran yang dimiliki.

\section{Analisis Bauran promosi Terhadap Peningkatan Volume Pembiayaan.}

Semua bauran promosi ini sangat potensial untuk meningkatkan volume pembiayaan dan juga dalam menghadapi persaingan antar bank. Oleh karena itu perusahaan perlu merencanakan dan memasukkan dalam rencana tahunan pelasanaan bauran promosi.

Dalam hal ini penulis mengamati dan mempelajari kebijakan perusahaan dalam melaksanakan bauran promosi untuk meningkatkan volume pembiayaan dapat mengambil sebuah keputusan bahwan bauran promosi yang sangat mempengaruhi peningkatan volume pembiayaan pada PT BPRS Rahmania Dana Sejahtera adalah pemasaran dari Mulut ke Mulut (words of Mouth) dan penjualan personal (personal selling). Ini terbukti dengan adanya pertumbuhan pembiayaan pada setiap tahun dan adanya tenaga marketing yang dikususkan untuk melakukan pemasaran dari mulut ke mulut dan penjualan personal.

Pemasaran dari Mulut ke Mulut (words of Mouth) dan penjualan personal (personal selling) merupakan kegiatan promosi yang paling banyak dan terus menerus dilakukan oleh perusahaan. Hal ini sangat mempengaruhi pengetahuan masyarakat tentang perusahaan dan produk yang ditawarkan dan juga menjaga citra perusahaan sebagai bank yang dekat dengan masyarakat, dan selalu hadir ketika dibutuhkan.

\section{Simpulan dan Saran Kesimpulan}

1. Perusahaan selama ini menjalankan ke delapan bauran promosi yaitu Periklanan (Advertising), Promosi Penjualan (Sales Promotion), Acara dan Pengalaman (Event \& Experiece), Hubungan Masyarakat atau publisitas (Public Relation), Pemasaran Langsung (Direct Marketing), Pemasaran Interaktif (Interactive Marketing), Pemasaran dari Mulut ke Mulut (words of Mouth), Penjualan Personal (Personal Selling), walaupun secara umum kegiatan promosi ini mempengaruhi peningkatan volume pembiayaan namun demikian belum semua bauran promosi optimal diterapkan.

2. Jenis bauran promosi yang sangat dominan dalam mempengaruhi pembiayaan adalah Pemasaran dari mulut ke mulut (words of mouth) dan Penjualan personal (personal selling) karena sesuai dengan pasar sasaran yang dimiliki oleh PT BPRS Rahmania Dana Sejahtera Kabupaten Bireuen yaitu menengah ke bawah.

3. Dilihat dari pencapaian volume pembiayaan perusahaan belum menerapkan bauran promosi secara baik dan terencana, ini terlihat dari pertumbuhan yang tidak merata di setiap tahunnya. Tetapi akan lebih efektif lagi 
apabila perusahaan melakukan perecanaan penerapan bauran promosi pada awal tahun dengan diikuti pengalokasian biaya untuk promosi.

4. Walaupun demikian adanya hubungan yang erat antara kegiatan bauran pemasran yang dilaksanakan dengan peningkatan volume pembiayaan yang diberikan. Dimana menurut penelitian terhadap nasabah pembiayaan apabilan karyawan melakukan promosi dengan cara dari mulut ke mulut dan berdialog langsung memberi keterangan terntang produk maka semakin meningkat calon nasabah yang menggunakan produk pembiayaan pada perusahaan PT BPRS Rahmania Dana Sejahtera Kabupaten Bireuen.

\section{Saran}

1. Biar pertumbuhan volumen pembiayaan semakin tahun semakin naik dan memiliki grafik yang baik maka perusahaan perlu melakukan perencanaan bauran promosi yang matang dengan langkah-langkah yang disusun secara sistematis dengan memperhatikan sumber daya yang dimiliki oleh perusahaan.

2. Dalam melaksanakan bauran promosi khusunya pemasaran dari mulut ke mulut dan perjualan personal perusahaan sebaiknya perlu dilakukan pelatihan peningkatan kemampuan karyawan dalam berkomunikasi dan menjalin berhubungan dengan berbagai kalangan yang menjadi pasar sasaran perusahaan.

3. Dalam melaksanakan periklanan (advertising) perusahaan sebaiknya memanfaatkan media informasi yang ada seperti membuat iklan pada surat kabar, radio, dan media online yang selama ini tidak pernah dilakukan oleh perusahaan. Selain itu juga dalam merancang iklan di media massa, perusahaan harus lebih memperhatikan isi pesan dan struktur pesan yang jelas, gambar yang menarik sehingga mempunyai daya tarik tersendiri bagi para pembaca dan pendengar. Dan perusahaan juga melihat pasar sasaran yang dituju oleh iklan yang dibuat sehingga tepat sasaran dengan tidak menyampingkan reaksi pesaing di perusahaan yang sama.

4. Perusahaan dapat meneliti kemungkinan penggunaan jenis bauran promosi yang lain seperti Promosi Penjualan (Sales Promotion), Acara dan Pengalaman (Event \& Experiece), Hubungan Masyarakat atau publisitas (Public Relation), Pemasaran Langsung (Direct Marketing), Pemasaran Interaktif (Interactive Marketing), dengan melibatkan semua karyawan sehingga peningkatan volume pembiyaan semakin meningkat dan masyarakat mengetahui produk perusahaan, dengan tidak merusak citra perusahaan sebagai perusahaan yang selalu memberi pelayanan baik kepada nasabah.

5. Perusahaan perlu mengadakan pelatihanpelatihan kepada tim marketing dan semua karyawan secara kontiu untuk meningkatkan pengetahuan tentang bagai mana menjadi sales yang baik, dan juga memberi pengetahuan yang lebih mendalam tentang kelebihan produkproduk yang dimiliki oleh perusahaan dengan produk-produk yang dimiliki oleh pesaing.

6. Manajemen perusahaan perlu melakukan pelatihan untuk membentuk kepribadian yang menarik terhadap tenaga marketing sehingga citra perusahaan terjaga dan tujuan perusahaan tercapai.

7. Perusahaan perlu merencanakan biaya yang akan digunakan untuk kegiatan promosi dan menambah tenaga sales yang tidak terikat yang membatu tenaga marketing dalam menjual produk pembiayaan.

8. Perusahaan agar lebih memperhatikan kesejahteraan dan memberi fasilitas yang lebih kepada tenaga marketing sehingga mereka termotivasi untuk mencapai target yang telah dibuat. 
Jurnal Sosial Humaniora Sigli (JSH)

p ISSN : 2615-3688

$e$ ISSN : 2716-0270

http://journal.unigha.ac.id/index.php/JSH

9. Perusahaan perlu melakukan edukasi (pendidikan) tetang perbankan syariah kepada calon nasabah dengan cara menggunakan brosur, menyediakan tenaga sales yang memberi informasi lansung dengan calon nasabah, dan bentuk-bentuk pendidikan lain yang bisa diberikan.

10. Perusahaan perlu meningkatkan pelayanan kepada nasabah dengan memberikan solusi bagi nasabah bermasalah, melayani dengan ikhlas nasabah yang datang, memberi informasi yang lengkap tentang produk kapada calon nasabah pembiayaan, dan juga memberikan keadilan kepada semua nasabah.

\section{DAFTAR PUSTAKA}

Kotler (2005), Manajemen Pemasaran, Jilid 1 dan 2. Jakarta : PT Indeks Kelompok Gramedia.

Kotler, Amstrong(2001),Prinsip-prinsip pemasaran, Edisi keduabelas, Jilid 1. Jakarta: Erlangga.

Handoko T Hani (2003), Manajemen Sumber Daya Manusia, Bandung : Salemba IV.

Djaslim Saladin dan Yevis Marty Oesman (2002),Intisari Pemasaran dan Unsur-Unsur Pemasaran, Cetakan kedua, Bandung : Linda Karya.

Buchari Alma (2006), Manajemen Pemasaran Jasa, Bandung : Alfabeta.

Djaslim Saladin (2004), Manajemen Pemasaran-Aanalisis Perencanaan, Pelaksanaan dan Pengendalian, Bandung : Alfabeta.

Djaslim Saladin, 2007, Manajemen Pemasaran, Bandung; Linda Karya.

Kasali, Rhenald. (2007).Membidik Pasar Indonesia Segmentasi Targeting, Positioning, Jakarta : PT Gramedia Pustaka Utama.

Kotler, Amstrong . 2010. Principles Of Marketing. 13 Edition. New Jersey . Upper Saddle River: Pearson Prentice Hall.

Antonio, Muhammad Syafi'i. 2001. Bank Syariah dari Teori Ke Praktek. Jakarta:Gema Insani.

Muhammad (2002;260), Manajemen Dana Bank Syariah, Jakarta : Alfabet 